\title{
Determination of the respective density distributions of low- and high-density lipoprotein particles in bovine plasma and lymph by immunoassay of apoproteins $A-I$ and B
}

\author{
S Auboiron', D Durand1, PM Laplaud2,3, \\ D Levieux ${ }^{4}$, D Bauchart ${ }^{1}$, MJ Chapman² \\ 1 Laboratoire d'Etude du Métabolisme Energétique, INRA Theix, 63122 St-Genes Champanelle; \\ 2 Unité de Recherche sur les Lipoprotéines et l'Athérogenèse (INSERM U321), \\ Hôpital de la Pitié, 75651 Paris Cedex 13; ${ }^{3}$ Laboratoire de Biochimie Médicale, \\ Faculté de Médecine et de Pharmacie, 87025 Limoges Cedex; \\ ${ }^{4}$ Laboratoire d'Immunologie des Ruminants, INRA Theix, 63122 St-Genes Champanelle, France
}

In our preliminary studies dealing with bovine plasma lipoproteins, we suggested that the spectrum of particles with $d>1.026 \mathrm{~g} / \mathrm{ml}$ could be divided into LDL (d 1.026-1.060 $\mathrm{g} / \mathrm{ml}$ ), light HDL (HDL d $1.060-1.091 \mathrm{~g} / \mathrm{ml}$ ) and heavy HDL $\left(H D L_{H} d 1.091-1.180 \mathrm{~g} / \mathrm{ml}\right.$ ) (Bauchart et al, 1989). However, subfractions corresponding to the $d 1.040-1.090 \mathrm{~g} / \mathrm{ml}$ range contain 2 types of lipoproteins with characteristics of LDL and HDL particles, respectively. Indeed, their separation by affinity chromatography on a heparin-Sepharose column showed the presence of 2 forms of HDL containing apoprotein (apo) A-I and one form of LDL containing apo $B$ with only slight traces apo A-I (Laplaud et al, 1989). Therefore, we directly estimated the respective density distributions of $L D L$ and HDL particles in bovine plasma and lymph by radial immunodiffusion (RID) assays of apo A-I and apo B. A 3 wk old preruminant calf $(46 \mathrm{~kg}, 600 \mathrm{~g} / \mathrm{d}$ body weight gain) was fed a milk substitute (22\% tallow and $23 \%$ protein). Plasma and lymph samples were obtained from chronic catheters inserted into the portal vein and the intestinal lymph duct. Lipoproteins of $d 1.006-1.210 \mathrm{~g} / \mathrm{ml}$ were separated by density gradient ultracentrifugation into 25 fractions. Their respective apo A-I and apo $B$ contents were determined by RID using specific rabbit antisera to bovine apo A-I and apo $B$.
Gradient distributions of apo A-I (d $1.046-1.180 \mathrm{~g} / \mathrm{ml} ; \max$ at $d 1.080 \mathrm{~g} / \mathrm{ml}$ ) and apo $\mathrm{B}(d 1.020-1.091 \mathrm{~g} / \mathrm{ml}$; max at $d$ $1.050 \mathrm{~g} / \mathrm{ml}$ ) were similar at the 2 sites. However, apo A-I and apo B concentrations were, respectively, 3 - and 2-fold higher in the plasma than in the lymph. An overlap between LDL and HDL particles occurred in the 1.040-1.091 $\mathrm{g} / \mathrm{ml}$ density range, as previously reported in the calf (Bauchart et al, 1989). Thus, apo $B$ was detected in $H D L_{L}$ fractions to an upper density limit of $d 1.091 \mathrm{~g} / \mathrm{ml}$ and apo A-I was detected in LDL fractions to a lower density limit of $1.040 \mathrm{~g} / \mathrm{ml}$. In the $1.040-1.091 \mathrm{~g} / \mathrm{ml}$ density range, the concentration ratio HDL/LDL calculated from compositional analysis, amounted to 2.9 (plasma) and 6.8 (lymph), which was comparable to results obtained by affinity chromatography (Laplaud et al, 1989). Our immunological technique could therefore be useful in studies of hepatic metabolism in the preruminant calf or in the dairy cow in which the ratio HDL/LDL (and apoA-l/B) varies markedly with the hormonal state during the gestation-lactation cycle.

Bauchart D, Durand D, Laplaud PM, Forgez P, Chapman MJ (1989) J Lipid Res 30, 14991514

Laplaud PM, Bauchart D, Durand D, Chapman MJ (1989) In: Intestinal Lipid and Lipoprotein Metabolism (Windler E, Greten H, eds), W Zuckschwerdt Verlag, München, 50-58 